Article

\title{
Thermal Treatment of Mercury Mine Wastes Using a Rotary Solar Kiln
}

\author{
Andrés Navarro ${ }^{1, *}$, Inmaculada Cañadas ${ }^{2}$ and José Rodríguez ${ }^{2}$ \\ 1 Department of Fluid Mechanics, Polytechnic University of Catalonia (UPC), Colón, 7, \\ 08222 Terrassa, Spain \\ 2 Solar Platform of Almería (PSA), P.O. Box 22, Tabernas, E-04200 Almería, Spain; \\ E-Mails: inmaculada.canadas@psa.es (I.C.); jose.rodriguez@psa.es (J.R.) \\ * Author to whom correspondence should be addressed; E-Mail: navarro@mf.upc.edu; \\ Tel.: +34-937-398-151; Fax: +34-937-398-101.
}

Received: 20 November 2013; in revised form: 24 January 2014 / Accepted: 24 January 2014 / Published: 28 January 2014

\begin{abstract}
Thermal desorption, by a rotary kiln of mercury contaminated soil and mine wastes, has been used in order to volatilize mercury from the contaminated medium. Solar thermal desorption is an innovative treatment that uses solar energy to increase the volatility of contaminants, which are removed from a solid matrix by a controlled air flow system. Samples of soils and mine wastes used in the experiments were collected in the abandoned Valle del Azogue mine (SE, Spain), where a complex ore, composed mainly of cinnabar, arsenic minerals (realgar and orpiment) and stibnite, was mined. The results showed that thermal treatment at temperatures $>400{ }^{\circ} \mathrm{C}$ successfully lowered the $\mathrm{Hg}$ content (2070-116 ppm) to $<15 \mathrm{mg} \mathrm{kg}^{-1}$. The lowest values of mercury in treated samples were obtained at a higher temperature and exposition time. The samples that showed a high removal efficiency $(>99 \%)$ were associated with the presence of significant contents of cinnabar and an equivalent diameter above $0.8 \mathrm{~mm}$.
\end{abstract}

Keywords: mercury; mine wastes; thermal desorption; rotary kiln

\section{Introduction}

Thermal treatment has been used to treat mercury-contaminated soil and waste by typical desorption units, which operate at temperatures ranging from 200 to $700{ }^{\circ} \mathrm{C}[1,2]$. In these systems, 
wastes are placed in the thermal desorber (direct-fired rotary kilns, indirectly heated screw, auger systems, etc.), after being heated, to volatilize the mercury. In these thermal devices, the off-gas generated is passed through a filtration system, where $\mathrm{Hg}^{0}$, finally, is collected [3,4]. Several mercury desorption experiments have demonstrated the feasibility of mercury removal at temperatures between 127 and $600{ }^{\circ} \mathrm{C}$ [5-8]. Experimental remediation of mercury-polluted soils by low-temperature thermal desorption has also shown mercury removal of over $99 \%$ in sand [8] and the volatilization of at least $99 \%$ of mercuric sulfide from polluted soil [5].

Besides, thermal treatment of mercury contaminated sediments showed that the percentage of mercury removal raises with the temperature during the treatment of solid matrices $[9,10]$. Furthermore, the treatment of mercury wastes from the chloralkali industry showed that treatment for $1 \mathrm{~h}$ at $800{ }^{\circ} \mathrm{C}$ allowed for a removal efficiency above $99.7 \%$ [11]. The results of the thermal desorption of mercury from different contaminated wastes showed that thermal decontamination at temperatures $>400{ }^{\circ} \mathrm{C}$ successfully decreased the $\mathrm{Hg}$ content [12-14].

Previous experiments of solar thermal desorption using a fluidized bed kiln showed that when soils and mine wastes were heated to $400-500{ }^{\circ} \mathrm{C}$, the mercury removal was significant [15]. The main objective of this research was to evaluate the potential of solar thermal desorption (STD) for the removal of mercury from mining contaminated soils and wastes. A rotary kiln system was designed and used to evaluate the effectiveness of STD and to verify its efficiency, comparing the results with previous experiments using other technologies.

\section{Materials and Methods}

\subsection{Characterization of Soils and Mine Wastes}

Samples of soils and mine wastes were collected in the Valle del Azogue mine (SE, Spain). The Valle del Azogue mine is located in the Betic Ranges and was exploited from approximately 1873 to 1890. The ore is composed of stibnite, cinnabar, arsenic minerals (realgar and orpiment), sphalerite, siderite, chalcopyrite, pyrite, quartz, calcite and barite [16]. The sampling area, comprising the North of Sierra Almagrera, is located $90 \mathrm{~km} \mathrm{NE}$ of the city of Almería (SE, Spain) in a semi-arid and intensively cultivated region. This abandoned mining area together with the Iberian Pyrite Belt and the Cartagena mining district is the oldest metallurgical and mining area in the Iberian Peninsula [16].

Approximately $1.5-\mathrm{kg}$ samples of mine wastes and soil (Figure 1) were manually extracted and crushed to 10 mesh in a jaw crusher, quartered and pulverized in an agate mortar, re-homogenized and repacked in plastic bags. Soil samples were taken from a depth of approximately $0-0.25 \mathrm{~m}$ and were sent to Actlabs (Ontario, Canada) with other mine samples. Au, Ag, As, Ba, Br, Ca, Ce, Co, Cr, Cs, $\mathrm{Eu}, \mathrm{Fe}, \mathrm{Hf}, \mathrm{Hg}, \mathrm{Ir}, \mathrm{La}, \mathrm{Lu}, \mathrm{Na}, \mathrm{Ni}, \mathrm{Nd}, \mathrm{Rb}, \mathrm{Sb}, \mathrm{Sc}, \mathrm{Se}, \mathrm{Sm}, \mathrm{Sn}, \mathrm{Sr}, \mathrm{Ta}, \mathrm{Th}, \mathrm{Tb}, \mathrm{U}, \mathrm{W}, \mathrm{Y}$ and $\mathrm{Yb}$ were quantitatively analyzed by instrumental neutron activation analysis (INAA), and $\mathrm{Mo}, \mathrm{Cu}, \mathrm{Pb}, \mathrm{Zn}, \mathrm{Ag}$, $\mathrm{Ni}, \mathrm{Mn}, \mathrm{Sr}, \mathrm{Cd}, \mathrm{Bi}, \mathrm{V}, \mathrm{Ca}, \mathrm{P}, \mathrm{Mg}, \mathrm{Tl}, \mathrm{Al}, \mathrm{K}, \mathrm{Y}$ and Be were analyzed by inductively coupled plasma emission spectroscopy (ICP-OES). The thermally treated samples were analyzed in the same way. The accuracy of the analytical data may be evaluated around $10 \%$, because of the heterogeneity of the solid samples. 
Figure 1. (a) General view of Valle del Azogue area. (b) Detail of the calcines and old metallurgical plant (location of MA4 and MA5 samples). (c) Detail of weathered superficial mine wastes (location of MA1 and MA2 samples).

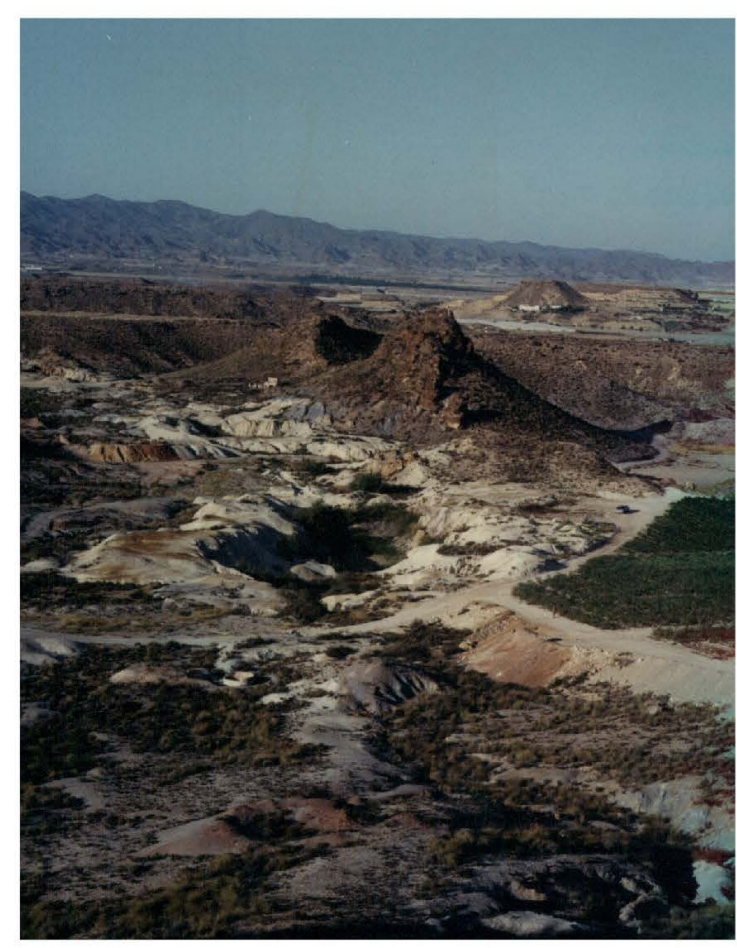

(a)

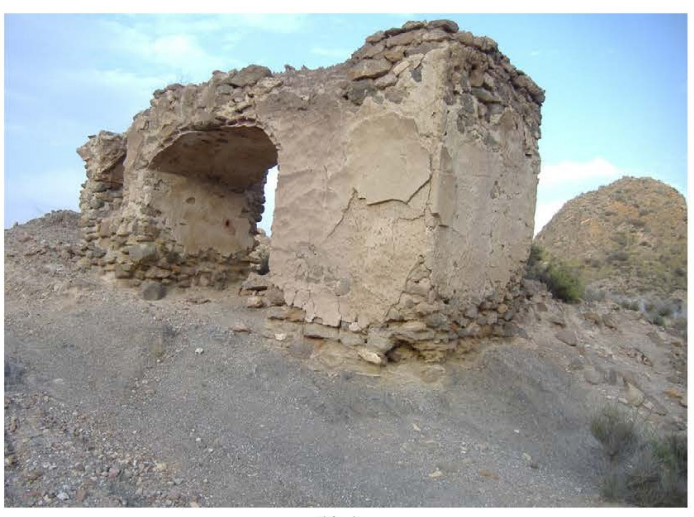

(b)

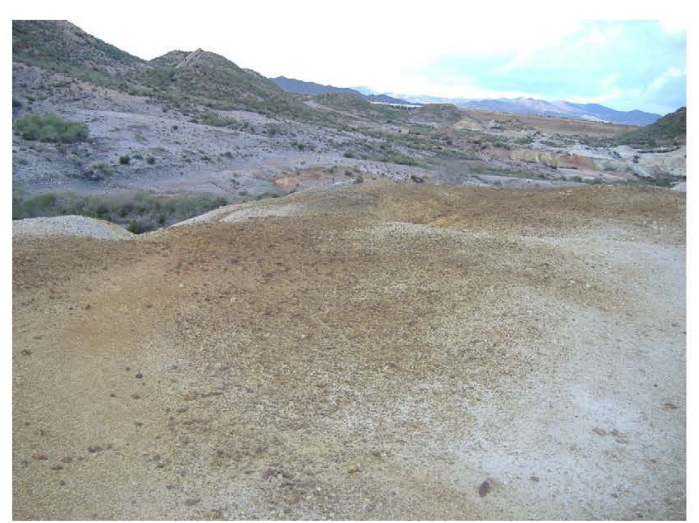

(c)

Hg phases were determined by solid-phase Hg-thermodesorption (SPTD), based on the specific thermal desorption or decomposition of $\mathrm{Hg}$ compounds from solids at different temperatures [16,17]. Mercury thermo-desorption curves were determined by means of an in-house apparatus, consisting of an electronically controlled heating unit and an $\mathrm{Hg}$ detection unit. Measurements were carried out at a heating rate of $0.5{ }^{\circ} \mathrm{C} / \mathrm{s}$ and a nitrogen-gas flow of $300 \mathrm{~mL} / \mathrm{min}$. The lowest level of detection under the given conditions is in the range of $40-50 \mathrm{ng}$ if all $\mathrm{Hg}$ is released within a single peak [17]. The results are depicted as $\mathrm{Hg}$-thermodesorption curves (Hg-TDC), which show the release of mercury versus temperature.

Mine waste samples were studied using transmitted and reflected light microscopy, X-ray diffraction (XRD) and scanning electron microscopy (SEM) with an attached energy dispersive X-ray spectroscopy system (EDS) at the Electronic Microscopy Laboratory of the Barcelona Autonomous University.

Furthermore, some physical characteristics of the soil were evaluated: pore size distribution, porosity, field capacity and bulk density (Table 1). Particle size distribution was determined by sieve analysis using aperture ranges between 4000 and $<350 \mu \mathrm{m}$. 
Table 1. Metal concentration in soils and mine wastes. Values in parts per million, except $\mathrm{Fe}(\%), \mathrm{Na}(\%), \mathrm{S}(\%), \mathrm{Ca}(\%), \mathrm{K}(\%)$ and $\mathrm{Mg}(\%)$. MW, mining wastes; CS, contaminated soil; CAL, calcine; IV, intervention values for soil remediation of the Dutch regulations [18].

\begin{tabular}{ccccccccc}
\hline Sample & MA1 & MA3 & MA5 & MA6 & MA2 & MA4 & MA7 & IV \\
\hline Type & MW & CS & CAL & MW & MW & CAL & CAL & --- \\
$\mathrm{As}($ ppm) & 598 & 143 & 1320 & 462 & 550 & 1,550 & 477 & 55 \\
$\mathrm{Ba}(\mathrm{ppm})$ & 59,800 & 7,350 & 20,400 & 15,800 & 78,900 & 93,000 & 42,800 & 625 \\
$\mathrm{Co}(\mathrm{ppm})$ & 9 & $<1$ & 25 & 8 & $<1$ & $<4$ & $<4$ & 240 \\
$\mathrm{Cr}(\mathrm{ppm})$ & $<20$ & 64 & $<60$ & 44 & 83 & $<43$ & $<9$ & 380 \\
$\mathrm{Fe}(\%)$ & 3.19 & 3.44 & 2.72 & 2.49 & 2.27 & 3.06 & 2.34 & --- \\
$\mathrm{Hg}(\mathrm{ppm})$ & 2,070 & 116 & $<25$ & 935 & 865 & 130 & 1,240 & 10 \\
$\mathrm{Na}(\%)$ & 0.83 & 1.03 & 2.23 & 1.18 & 0.64 & 0.69 & 1.24 & --- \\
$\mathrm{Sb}(\mathrm{ppm})$ & 2,880 & 357 & $>10,000$ & 2,000 & 3,290 & $>10,000$ & 2,850 & 15 \\
$\mathrm{Se}(\mathrm{ppm})$ & $<18$ & $<6$ & $<37$ & $<9$ & $<10$ & $<31$ & $<3$ & $0.7 *$ \\
$\mathrm{Ta}(\mathrm{ppm})$ & $<2.5$ & $<0.5$ & $<6.0$ & $<2.5$ & $<0.5$ & $<3.3$ & $<0.5$ & $1 *$ \\
$\mathrm{Th}(\mathrm{ppm})$ & $<2.0$ & 11.6 & $<7.0$ & 7.2 & 6.5 & $<3.8$ & 4.8 & --- \\
$\mathrm{U}(\mathrm{ppm})$ & $<6.0$ & $<0.9$ & $<15.0$ & $<3.0$ & $<2.9$ & $<8.9$ & $<1.9$ & --- \\
$\mathrm{W}(\mathrm{ppm})$ & $<5$ & $<1$ & $<13$ & $<4$ & $<1$ & $<6$ & $<1$ & --- \\
$\mathrm{Ag}(\mathrm{ppm})$ & 16.5 & 1.1 & 58.7 & 15.7 & 25.7 & 34.5 & 15.3 & $15 * *$ \\
$\mathrm{Cu}(\mathrm{ppm})$ & 36 & 27 & 32 & 38 & 31 & 42 & 28 & 190 \\
$\mathrm{Cd}(\mathrm{ppm})$ & 3.8 & 1 & 5 & 1.4 & 10.6 & 6.6 & 0.8 & 12 \\
$\mathrm{Mo}(\mathrm{ppm})$ & 4 & $<1$ & $<1$ & 1 & 2 & $<1$ & $<1$ & 200 \\
$\mathrm{~Pb}(\mathrm{ppm})$ & 213 & 134 & 1,820 & 512 & 1,210 & 1,190 & 536 & 530 \\
$\mathrm{Ni}(\mathrm{ppm})$ & 25 & 55 & 20 & 34 & 20 & 23 & 18 & 210 \\
$\mathrm{Zn}(\mathrm{ppm})$ & 1,200 & 424 & 503 & 1,330 & 3,190 & 2,230 & 854 & 720 \\
$\mathrm{~S}(\%)$ & 2.62 & 0.47 & 2.81 & 1.49 & 2.05 & 2.02 & 0.28 & --- \\
$\mathrm{Be}(\mathrm{ppm})$ & 2 & 3 & 1 & 3 & 2 & 2 & 2 & $1.1 *$ \\
$\mathrm{Ca}(\%)$ & 1.7 & 2.49 & 7.33 & 2.28 & 0.27 & 3.09 & 0.12 & --- \\
$\mathrm{K}(\%)$ & 1.86 & 1.98 & 1.14 & 2.07 & 1.87 & 1.45 & 1.49 & --- \\
$\mathrm{Mg}(\%)$ & 0.46 & 1.28 & 0.94 & 0.69 & 0.23 & 1.16 & 0.54 & --- \\
$\mathrm{Mn}(\mathrm{ppm})$ & 83 & 823 & 64 & 108 & 53 & 171 & 31 & --- \\
$\mathrm{V}(\mathrm{ppm})$ & 51 & 91 & 25 & 63 & 57 & 30 & 53 & $42 *$ \\
\hline
\end{tabular}

Notes: * target values for sediments; ** indicative values of serious contamination for sediments.

\subsection{Rotary Kiln}

In this study, an experimental rotary kiln was used in the solar devices of the Solar Platform of Almería (PSA-CIEMAT (Centro de Investigaciones Energéticas, Mediombientales y Tecnológicas)) in Spain. This solar system (Figures 2 and 3) essentially consists of a continuous solar-tracking flat heliostat, a parabolic concentrator mirror (collector), an attenuator (shutter) and an experimental kiln located in the concentrator focus center [19].

The heliostat reflects horizontal and parallel solar rays on the parabolic collector, which again reflects and concentrates them in its center, located at the rotary kiln-window (Figure 3). When the 
shutter is $100 \%$ opened and with a direct solar irradiance of $100 \mathrm{~W} / \mathrm{m}^{2}$, the focus is characterized by an irradiance peak of $3051 \mathrm{~kW} / \mathrm{m}^{2}$, a total power of $70 \mathrm{~kW}$ and a focal diameter of $26 \mathrm{~cm}$.

The experimental rotary kiln consists of a rotating cylindrical device, where heat is transferred through a quartz window focused to a parabolic collector (Figure 3). The contaminants are volatilized and transported to the emission control system by a controlled air-flow system. The process gas is filtered through an activated carbon unit, where mercury and other contaminants are adsorbed.

Figure 2. Experimental solar system comprising a continuous solar-tracking flat heliostat, a parabolic concentrator mirror (collector), an attenuator (shutter) and the experimental kiln located in the concentrator focus center.

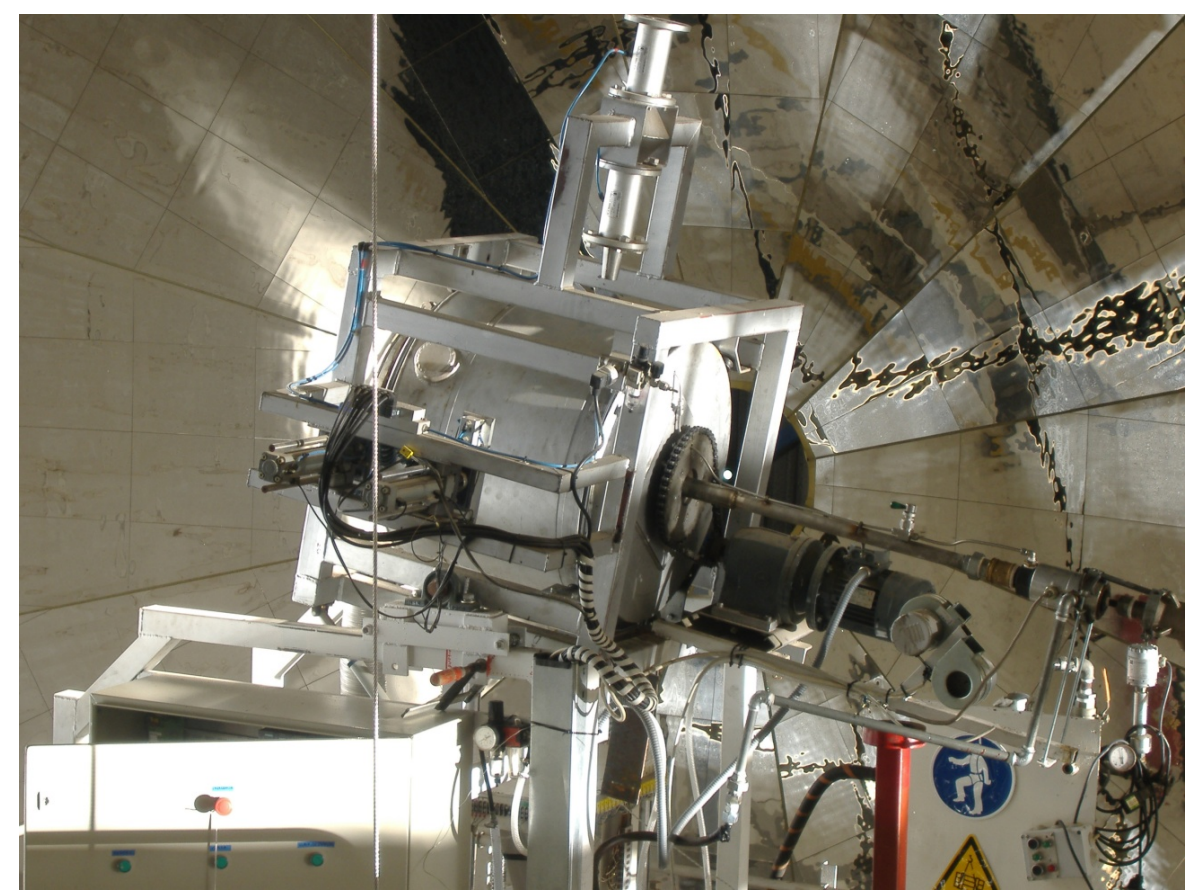

Figure 3. Detail of the rotary kiln and the quartz window.

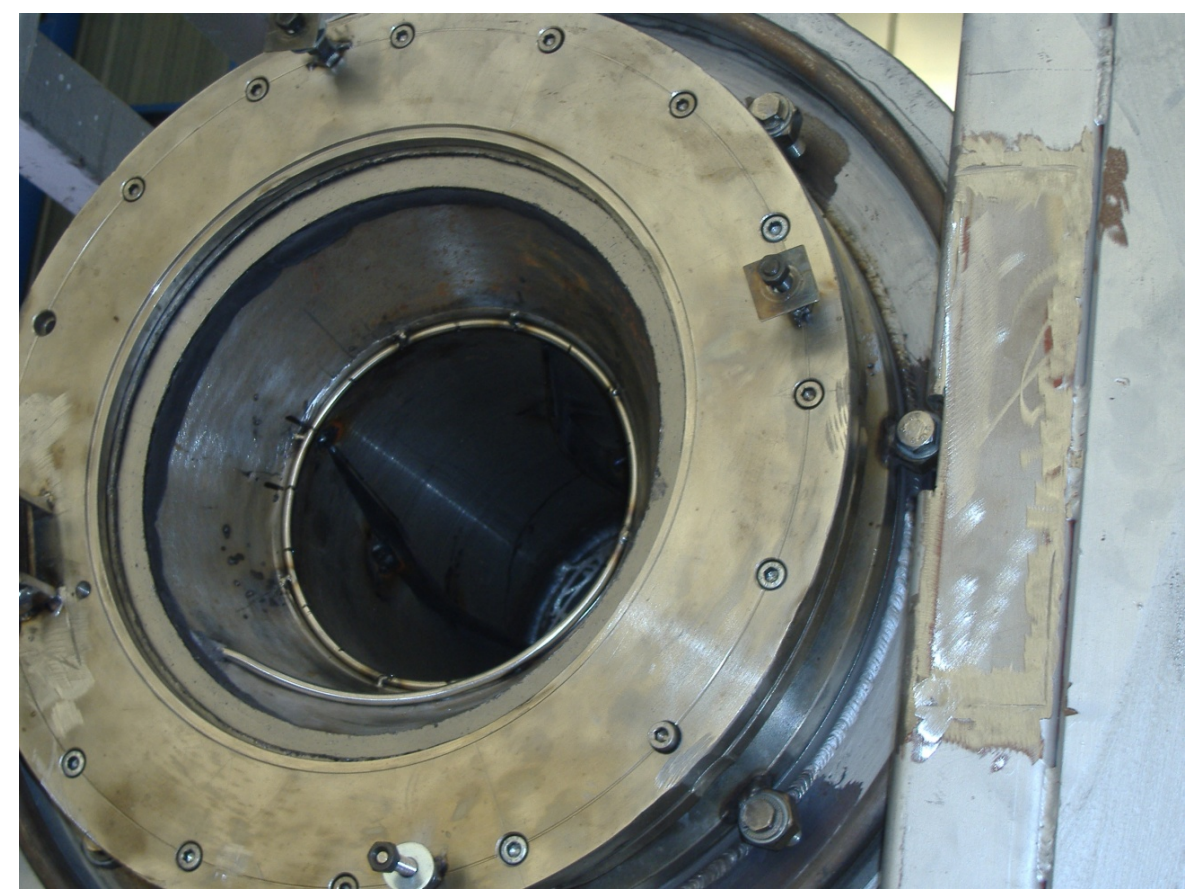




\section{Results and Discussion}

\subsection{Geochemistry of Soils and Mine Wastes: Physical Characteristics}

The mean concentrations of mercury and other metals in the soil and mine waste samples are shown in Table 1. The total mercury concentration in soils and wastes from the Valle del Azogue area varies between $<25$ and $2070 \mathrm{mg} / \mathrm{kg}$. In the waste samples, Pb contents vary between 134 and $1820 \mathrm{mg} / \mathrm{kg}$. Furthermore, high concentrations of $\mathrm{As}, \mathrm{Ba}, \mathrm{Sb}$ and $\mathrm{Zn}$ were detected, above the intervention values for soil remediation of international regulations (Table 1). Due to the mining and metallurgical activities, plants have disappeared or have been severely affected by the very high mercury and metal content in most part of this area [20].

The main physical parameters of soils used in the experiments showed a mean bulk density of $1450 \mathrm{~kg} / \mathrm{m}^{3}$, a mean porosity of 0.40 and a mean field capacity of 0.08 (Table 2). The particle sizes showed that the abandoned mine wastes and contaminated soils are largely comprised of sandy material fraction (Figure 4). The coarser sample 1 is associated with mining wastes and, possibly, to overburdened ore deposit. Remaining samples have a particle size that may be suitable for thermal treatment.

Table 2. The main physical characteristics of soils used in the column experiments.

\begin{tabular}{ccccc}
\hline Sample & $\mathbf{d}_{\mathbf{e}}$ & $\boldsymbol{\varepsilon}$ & $\boldsymbol{\rho}$ & $\mathbf{F C ~ ( \% )}$ \\
\hline MA1 & 3.4 & --- & 1330 & 8 \\
MA2 & 1.8 & 0.34 & 1430 & 8 \\
MA3 & 1.0 & 0.45 & 1310 & 10 \\
MA4 & 0.8 & --- & 1410 & 10 \\
MA5 & 0.5 & --- & 1470 & 7 \\
MA6 & 1.9 & --- & 1400 & 8 \\
MA7 & 1.3 & 0.41 & 1490 & 8 \\
\hline
\end{tabular}

Notes: $\mathrm{d}_{\mathrm{e}}$, equivalent diameter $(\mathrm{mm})$ obtained by sieve analysis; $\varepsilon$, porosity obtained by water displacement in a test tube; $\rho$, bulk density $\left(\mathrm{kg} / \mathrm{m}^{3}\right) ; \mathrm{FC}$, field capacity.

Figure 4. (a) Grain size distribution of samples MA1 to MA3. (b) Grain size distribution of samples MA4 to MA7.

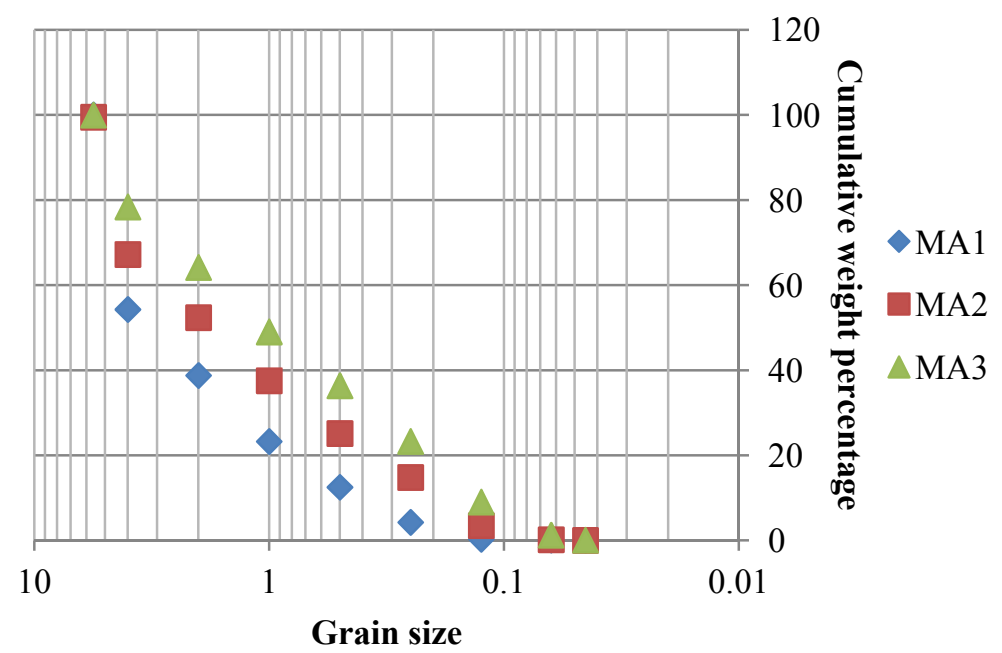

(a) 
Figure 4. Cont.

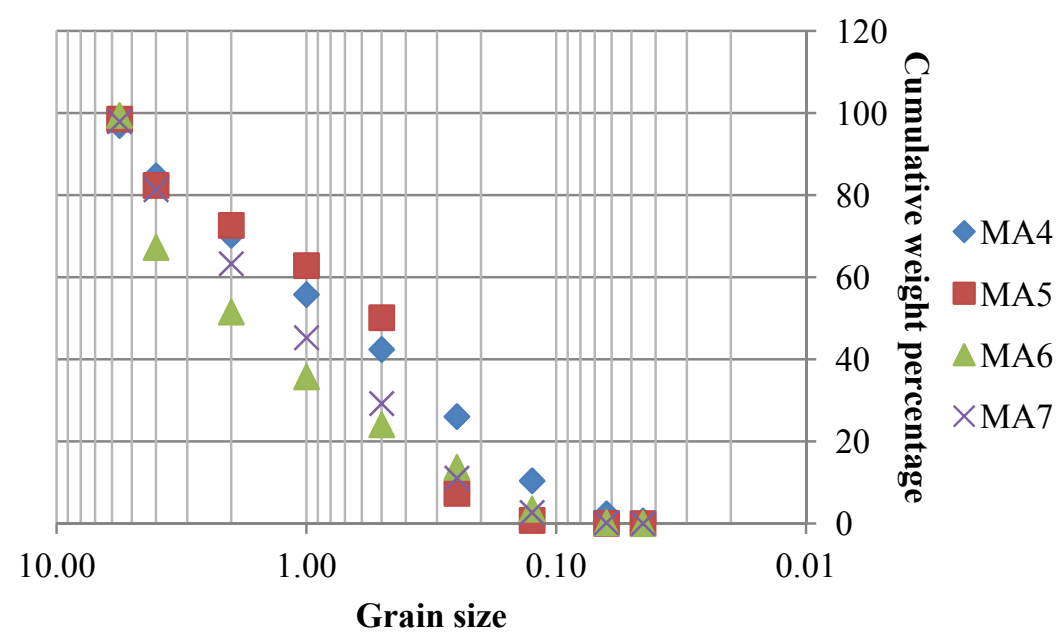

(b)

Hg-thermodesorption curves (Hg-TDC) belonging to mining wastes, soils and calcine samples showed the predominant release of $\mathrm{Hg}$ in two temperature ranges: $200-250{ }^{\circ} \mathrm{C}$ and $300-330{ }^{\circ} \mathrm{C}$ (Figure 5). The first temperature range was assigned to a release of $\mathrm{Hg}$ from the soil matrix components based on the Hg-TDCs of standard materials [17]. Thus, we assume that most of the $\mathrm{Hg}$ present in the calcine material is bound to mineral components mainly by iron oxides, which were formed when the cinnabar-bearing ore was being roasted. It has been suggested in earlier studies that $\mathrm{Hg}^{0}$ formed during thermal breakdown of cinnabar is re-condensed during the cooling of the material and adsorbed to iron oxide surfaces [21]. In addition to matrix-bound $\mathrm{Hg}$, some calcine samples contain traces of cinnabar. This could be explained by an incomplete breakdown of cinnabar ore during the roasting process.

Figure 5. Hg-thermodesorption curves (Hg-TDC) of samples: (a) MA1 (mining wastes); (b) MA2 (mining wastes); (c) MA3 (contaminated soil); (d) MA4 (calcine); (e) MA5 (calcine); (f) MA6 (mining wastes); and (g) MA7 (calcine).

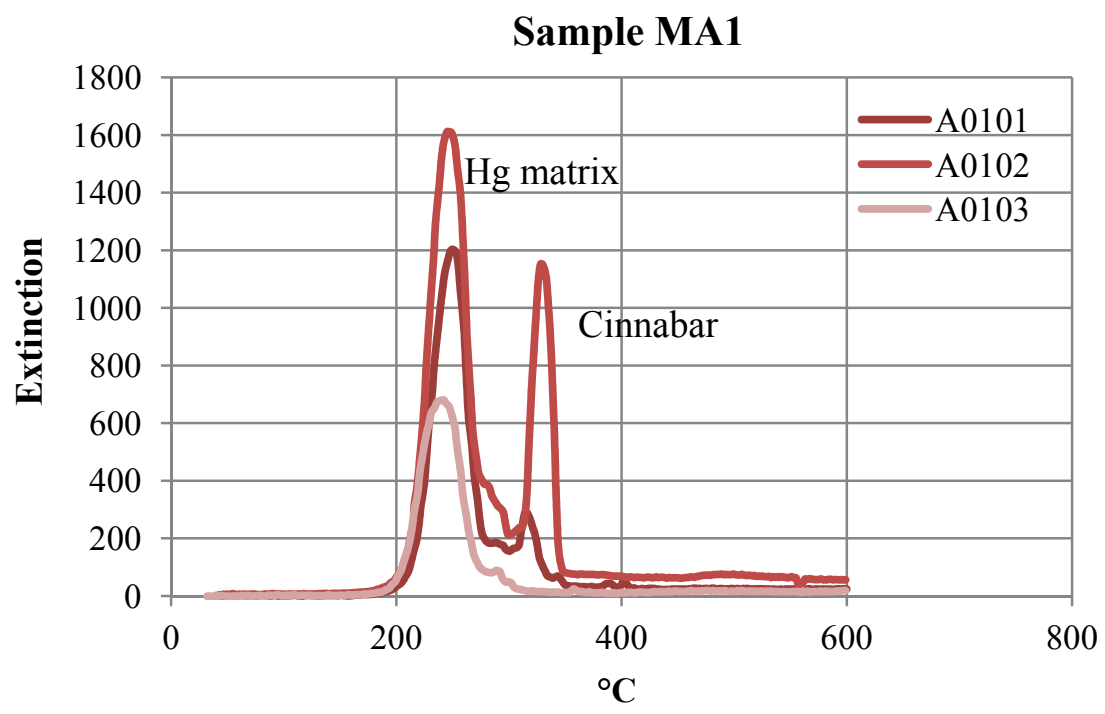

(a) 
Figure 5. Cont.

Sample MA2

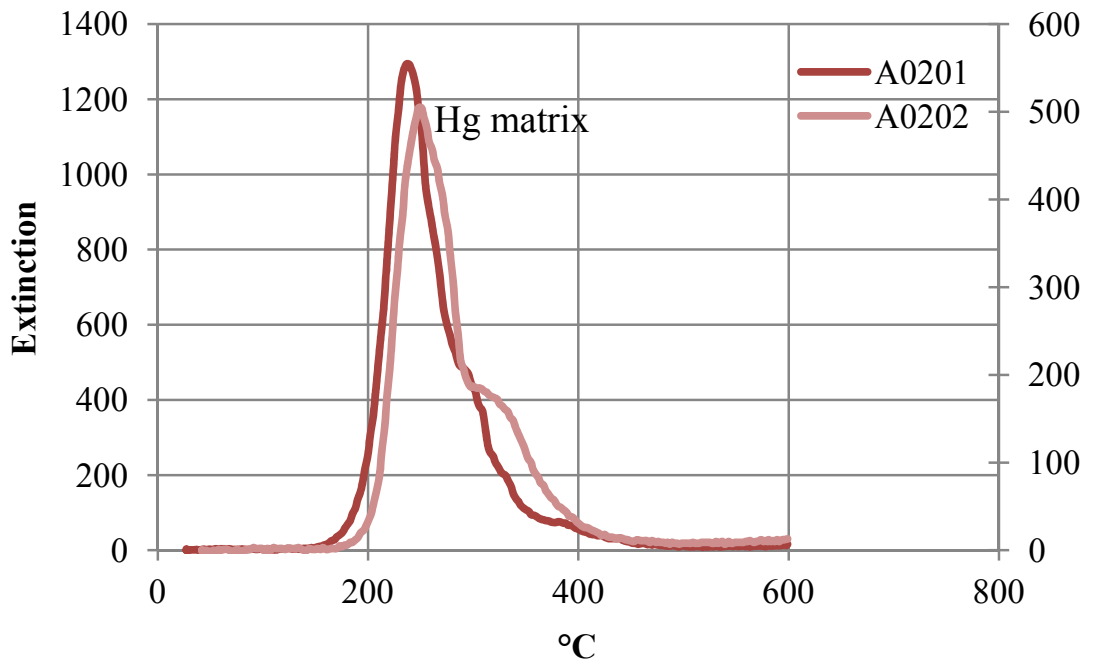

(b)

Sample MA3

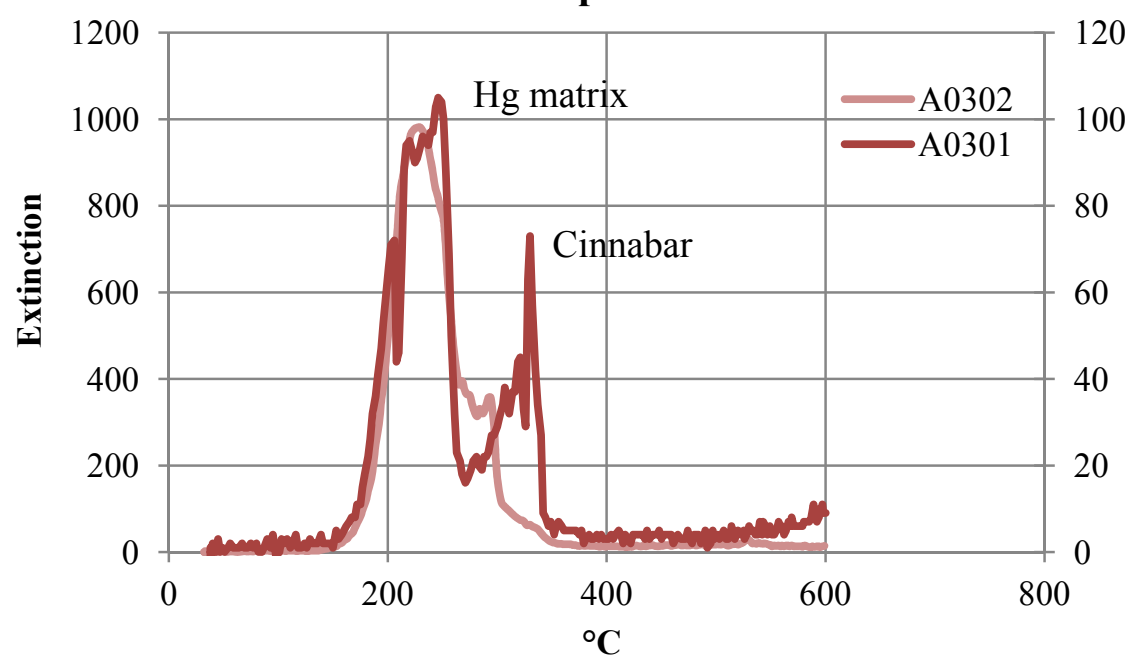

(c)

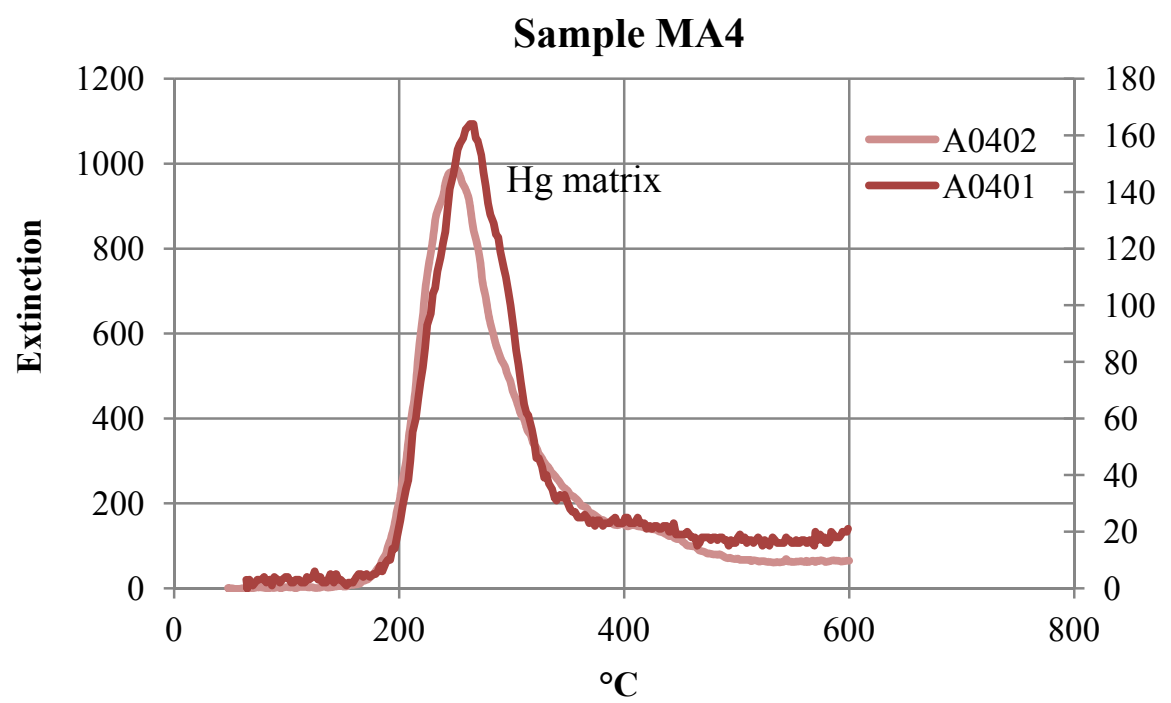

(d) 
Figure 5. Cont.

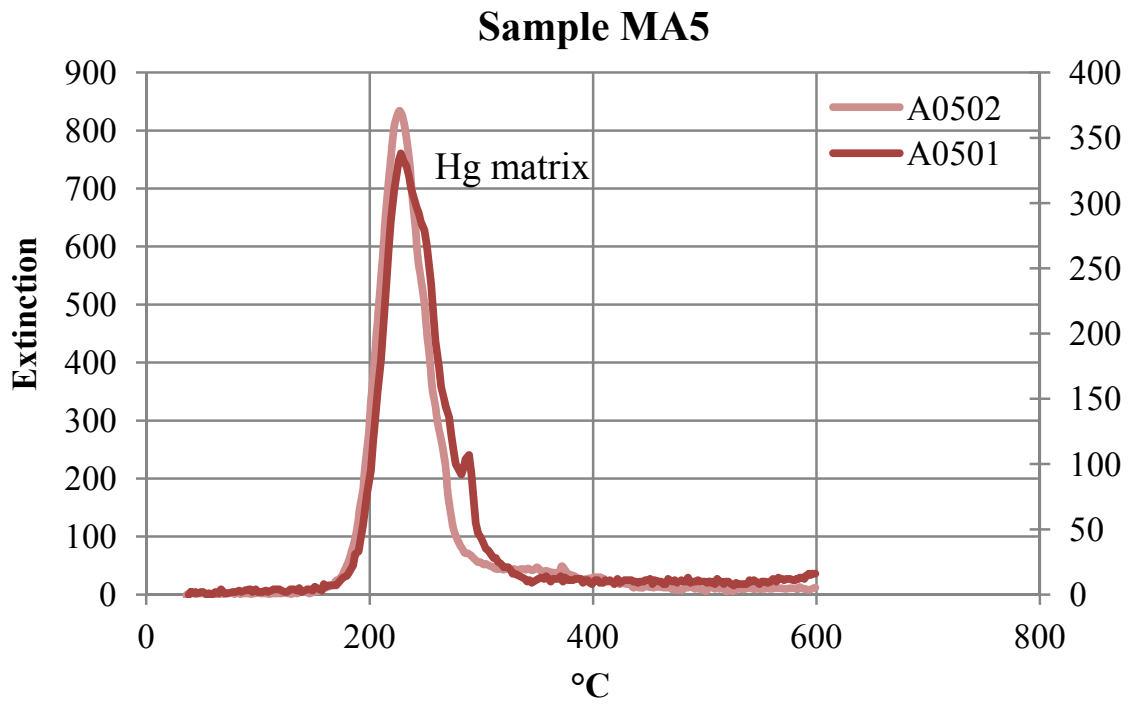

(e)

Sample MA6

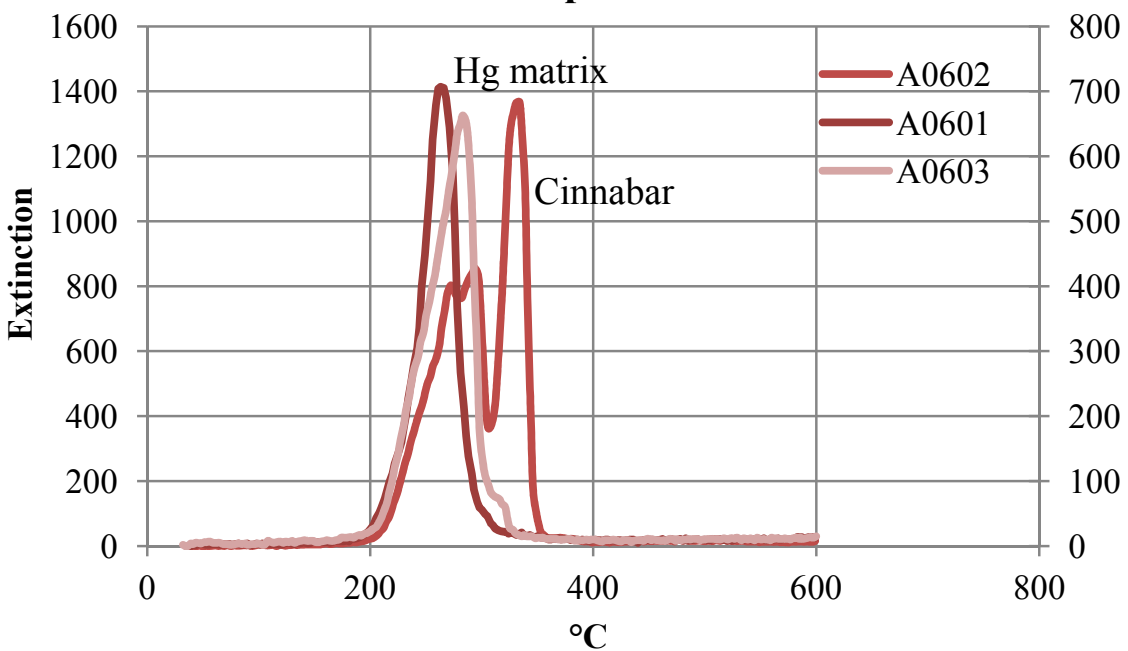

(f)

Sample MA7

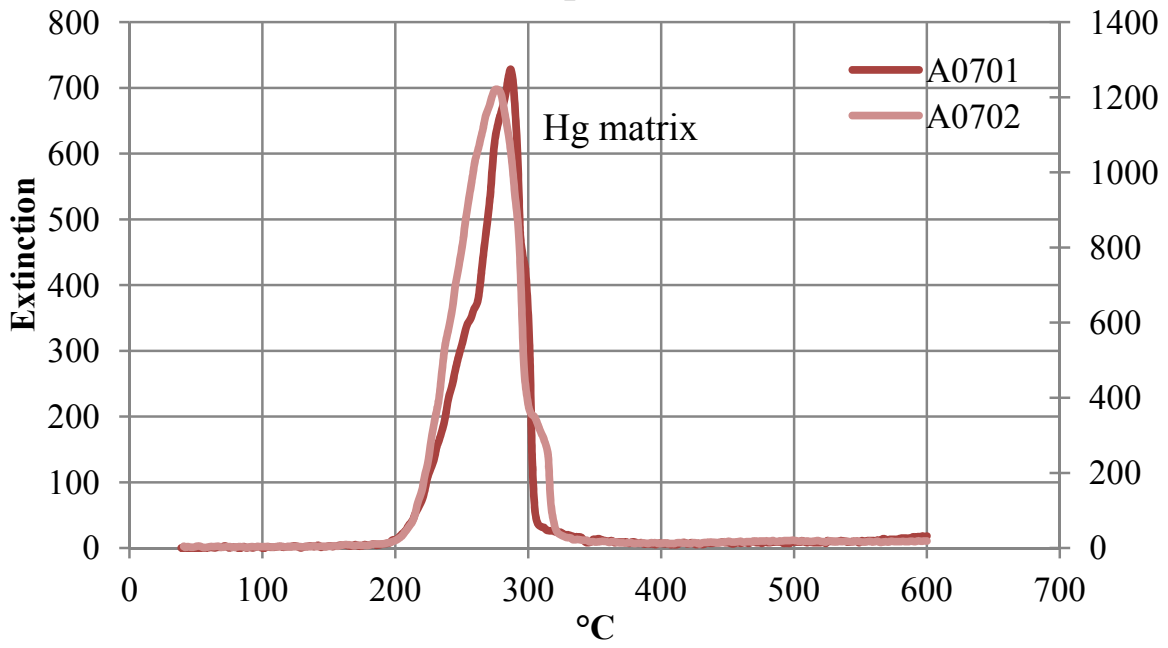

(g) 
The second temperature range was assigned to $\mathrm{Hg}$ release from cinnabar, which was the predominant $\mathrm{Hg}$ mineral in contaminated soils and mining wastes (host rock and low-grade stockpiles). Cinnabar and a possible $\mathrm{Hg}$ sulfate were also detected in several samples [16]. No free metallic $\mathrm{Hg}$, which is typically released at temperatures below $100{ }^{\circ} \mathrm{C}$, was found in any of the samples studied.

Mercury phase characterization by soil sample X-ray showed the presence of cinnabar $(\mathrm{HgS})$, corderoite $\left(\mathrm{Hg}_{3} \mathrm{~S}_{2} \mathrm{Cl}_{2}\right)$, laffittite $\left(\mathrm{AgHgAsS}_{3}\right)$, metacinnabar $((\mathrm{Hg}) \mathrm{S})$, shakhovite $\left(\mathrm{Hg}_{4} \mathrm{SbO}_{5}(\mathrm{OH})_{3}\right)$, schuetteite $\left(\mathrm{Hg}_{3}\left(\mathrm{SO}_{4}\right) \mathrm{O}_{2}\right)$ and tiemannite (HgSe) (Table 3). The proportionally $\mathrm{Hg}$ predominant phase is cinnabar, which is concordant with the SPTD analyses.

The detailed SEM and EDS systems study of mine waste samples showed the presence of primary and secondary cinnabar associated with barite, pyrite and botryoidal pyrite. Furthermore, SEM observations showed several small particles containing both $\mathrm{Hg}$ and $\mathrm{Cl}$ and that may be associated with calomel $\left(\mathrm{Hg}_{2} \mathrm{Cl}_{2}\right)$. Moreover, some particles containing both $\mathrm{Hg}$ and $\mathrm{Br}$ were observed and may be associated with kuzminite $\left(\mathrm{Hg}_{2}(\mathrm{Br}, \mathrm{Cl})_{2}\right)[15,22]$. Besides, in the gangue, main minerals are quartz, barite and silicates.

Table 3. Identified minerals in the Valle del Azogue soil and mine wastes and dominant $\mathrm{Hg}$ minerals from $\mathrm{Hg}$-thermodesorption curves. Modified from Navarro et al. [22].

\begin{tabular}{|c|c|}
\hline Minerals & Formula \\
\hline \multicolumn{2}{|c|}{ Primary minerals (soils and mine wastes) } \\
\hline Quartz * & $\mathrm{SiO}_{2}$ \\
\hline Barite * & $\mathrm{Ba}\left(\mathrm{SO}_{4}\right)$ \\
\hline Cinnabar * & $\mathrm{HgS}$ \\
\hline Dolomite * & $\mathrm{CaMg}\left(\mathrm{CO}_{3}\right)_{2}$ \\
\hline Calcite * & $\mathrm{Ca}\left(\mathrm{CO}_{3}\right)$ \\
\hline Huntite * & $\mathrm{Mg}_{3} \mathrm{Ca}\left(\mathrm{CO}_{3}\right)_{4}$ \\
\hline Stibnite $*$ & $\mathrm{Sb}_{2} \mathrm{~S}_{3}$ \\
\hline Realgar * & AsS \\
\hline Orpiment & $\mathrm{As}_{2} \mathrm{~S}_{3}$ \\
\hline Chalcopyrite & $\mathrm{CuFeS}_{2}$ \\
\hline Arsenian pyrite * & $\mathrm{Fe}\left(\mathrm{S}_{1-x} \mathrm{As}_{x}\right)_{2}$ \\
\hline Sphalerite & $\mathrm{ZnS}$ \\
\hline Orthoclase & $\mathrm{K}(\mathrm{Al}, \mathrm{Fe}) \mathrm{Si}_{2} \mathrm{O}_{8}$ \\
\hline Gold & $\mathrm{Au}$ \\
\hline Illite * & $\mathrm{Al}_{4}\left(\mathrm{Si}_{4} \mathrm{O}_{10}\right)(\mathrm{OH})_{8}$ \\
\hline \multicolumn{2}{|c|}{ Secondary minerals (soils and mine wastes) } \\
\hline $\mathrm{Hg}^{0}$ & $\mathrm{Hg}$ \\
\hline Metacinnabar & $\mathrm{HgS}$ \\
\hline Goethite & $\mathrm{FeOOH}$ \\
\hline Jarosite & $\mathrm{KFe}_{3}\left(\mathrm{SO}_{4}\right)_{2}(\mathrm{OH})_{6}$ \\
\hline Hematite & $\mathrm{Fe}_{2} \mathrm{O}_{3}$ \\
\hline Inyoite & $\mathrm{CaB}_{3} \mathrm{O}_{3}(\mathrm{OH})_{5} \cdot 4 \mathrm{H}_{2} \mathrm{O}$ \\
\hline Ferrihydrite & $\mathrm{Fe}(\mathrm{OH})_{3}$ \\
\hline Kaolinite & $\mathrm{KAl}_{2} \mathrm{Si}_{3} \mathrm{AlO}_{10}(\mathrm{OH})_{2} \cdot 3 \mathrm{H}_{2} \mathrm{O}$ \\
\hline Gypsum & $\mathrm{Ca}\left(\mathrm{SO}_{4}\right) \cdot 2 \mathrm{H}_{2} \mathrm{O}$ \\
\hline
\end{tabular}


Table 3. Cont.

\begin{tabular}{cc}
\hline Minerals & Formula \\
\hline Secondary minerals (soils and mine wastes) & \\
Schuetteite & $\mathrm{Hg}_{3}\left(\mathrm{SO}_{4}\right) \mathrm{O}_{2}$ \\
Tiemannite & $\mathrm{HgSe}$ \\
Corderoite & $\mathrm{Hg}_{3} \mathrm{~S}_{2} \mathrm{Cl}_{2}$ \\
Shakhovite & $\mathrm{Hg}_{4} \mathrm{SbO}_{5}(\mathrm{OH})_{3}$ \\
Calomel & $\mathrm{Hg}_{2} \mathrm{Cl}_{2}$ \\
Kuzminite & $\mathrm{Hg}_{2}(\mathrm{Br}, \mathrm{Cl})_{2}$ \\
\hline Sample & Dominant $\mathbf{H g}$-mineral phase \\
\hline MA1 (mining wastes) & $\mathrm{Hg}$ matrix, cinnabar \\
MA2 (mining wastes) & $\mathrm{Hg}$ matrix \\
MA3 (contaminated soil) & $\mathrm{Hg}$ matrix, cinnabar \\
MA4 (calcine) & $\mathrm{Hg}$ matrix \\
MA5 (calcine) & $\mathrm{Hg}$ matrix \\
MA6 (mining wastes) & $\mathrm{Hg}$ matrix, cinnabar \\
MA7 (calcine) & $\mathrm{Hg}$ matrix \\
\hline
\end{tabular}

Note: * high-medium abundant minerals.

\subsection{Thermal Desorption Experiments}

Rotary kiln experiments were conducted under global radiation of approximately $800 \mathrm{~W} / \mathrm{m}^{2}$ with an exposure time of between 120 and $300 \mathrm{~min}$. Table 4 shows the initial and final mercury concentration in the treated samples and the mercury removal efficiency of each experiment. Efficiency was calculated as the percentage of removed mercury with respect to the untreated sample.

Table 4. Results of mercury removal by solar thermal desorption with the rotary kiln. US, untreated sample; TS, treated sample; RE, removal efficiency; T, mean temperature reached.

\begin{tabular}{ccccc}
\hline Sample & Hg (US) (ppm) & Hg (TS) (ppm) & RE (\%) & T $\left({ }^{\circ} \mathbf{C}\right)$ \\
\hline MA1 & 2070 & $<10$ & 99.5 & 550 \\
MA3 & 116 & $<1$ & 99.1 & 750 \\
MA5 & $<25$ & $<25$ & ---- & 790 \\
MA6 & 935 & $<5$ & 99.4 & 700 \\
MA2 & 865 & $<5$ & 99.4 & $700-800$ \\
MA4 & 130 & $<15$ & 88.4 & $700-800$ \\
MA7 & 1240 & $<5$ & 99.6 & $700-800$ \\
\hline
\end{tabular}

The results showed that the lowest values of mercury in treated samples were consistently obtained at higher exposition times and desorption temperatures of the main $\mathrm{Hg}$ minerals (Table 5). However, in sample MA1, a low temperature exposition allowed for a greater mercury removal (99.5\%). Besides, the lead removal in the thermal experiments was also significant, since the removal efficiency reached values of $48.5 \%-89.0 \%$ in all samples, with the exception of the MA1 and MA2 samples (Table 6). At lower temperatures, $\mathrm{Pb}$ was not removed, suggesting the presence of $\mathrm{Pb}$ as a trace metal in other minerals other than galena, such as barite and pyrite, as the volatilization 
temperature of galena is really low $\left(503\right.$ to $\left.654{ }^{\circ} \mathrm{C}\right)$. High amounts of $\mathrm{Pb}$ in pyrite from the study area have been reported, reaching concentrations up to $0.29 \%$ in weight.

Table 5. Desorption temperatures of different mercury minerals.

\begin{tabular}{cc}
\hline Phase & Desorption temperature $\left({ }^{\circ} \mathbf{C}\right)$ \\
\hline $\mathrm{Hg}^{0}$ & $<100$ \\
$\mathrm{Hg}_{2} \mathrm{Cl}_{2}$ & 170 \\
$\mathrm{HgCl}_{2}$ & $<250,220$ \\
$\mathrm{HgO}$ & $420-550$ \\
$\mathrm{HgSO}$ & $450-500$ \\
$\mathrm{HgS}$ (cinnabar) & $310-330$ \\
$\mathrm{Hg}$ in pyrite & $>450$ \\
$\mathrm{Hg}$ in Sphalerite & 600 \\
$\mathrm{Hg}$ matrix & $200-300$ \\
\hline
\end{tabular}

Table 6. Results of lead removal by solar thermal desorption with the rotary kiln. US, untreated sample; TS, treated sample; RE, removal efficiency; $\mathrm{T}$, mean temperature reached.

\begin{tabular}{ccccc}
\hline Sample & $\mathbf{P b}$ (US) (ppm) & $\mathbf{P b}(\mathbf{T S}) \mathbf{( p p m )}$ & $\mathbf{R E}(\%)$ & $\mathbf{T}\left({ }^{\circ} \mathbf{C}\right)$ \\
\hline MA1 & 213 & 245 & --- & 550 \\
MA3 & 134 & 69 & 48.5 & 750 \\
MA5 & 1820 & 795 & 56.3 & 790 \\
MA6 & 512 & 260 & 49.2 & 700 \\
MA2 & 1210 & 745 & 38.4 & $700-800$ \\
MA4 & 1190 & 130 & 89.0 & $700-800$ \\
MA7 & 536 & 68 & 87.3 & $700-800$ \\
\hline
\end{tabular}

Figure 6 reveals the decrease of mercury with temperature in sample MA7, coinciding with a removal above $99 \%$ when the thermal treatment reached $400{ }^{\circ} \mathrm{C}$, above the decomposition temperature of cinnabar $\left(310-330{ }^{\circ} \mathrm{C}\right)$. Mercury removal became highly efficient (more than $90 \%$ removal) when the temperature was higher than $400{ }^{\circ} \mathrm{C}$. Similar results were reported by other studies $[6,11,15]$.

Figure 6. Evolution of mercury removal during the treatment of sample MA7.

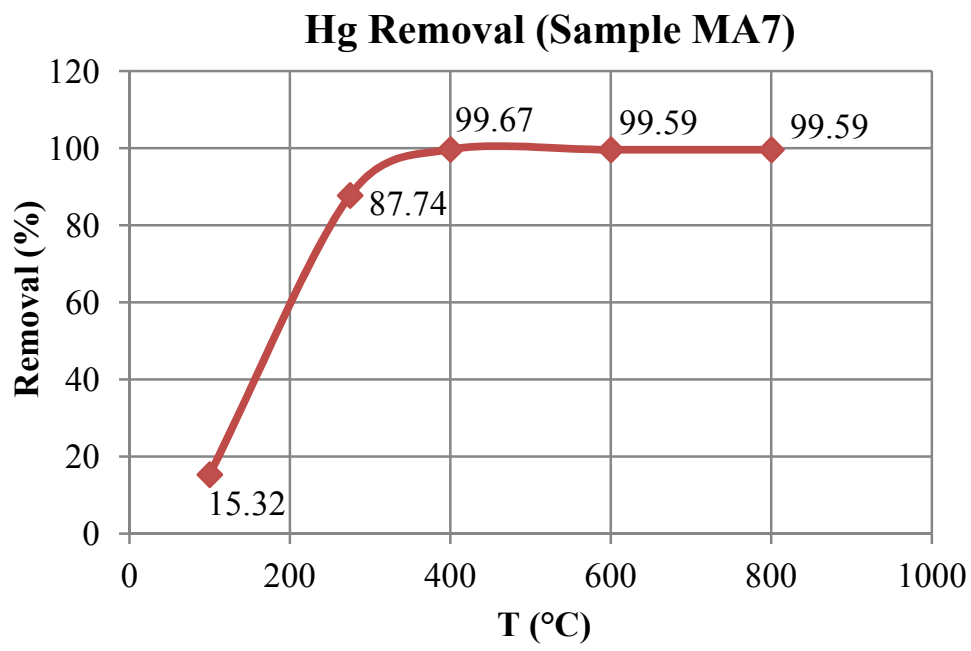


This temperature may be the lowest limit treatment in order to remove mercury from solid wastes associated with cinnabar and matrix-bound $\mathrm{Hg}$. However, if contaminated samples comprise mercury associated with pyrite, sphalerite and $\mathrm{HgSO}_{4}$, the treatment temperature should be over $600{ }^{\circ} \mathrm{C}$, above the decomposition temperature of these mineral phases $[15,23,24]$. Moreover, the experimental results showed that the rotary kiln is more efficient than a fluidized-bed reactor in order to remove mercury from contaminated soils and wastes. The results reported by Navarro et al. [15] showed a lower removal efficiency $(4.5 \%-76.0 \%)$, using similar samples and a solar fluidized reactor.

Furthermore, experimental results showed that metalloids, like $\mathrm{Sb}$, Se and As, remain in treated samples at elevated concentrations. Thus, thermal treatment has been shown to cause, possibly, a stronger binding between the metal/metalloid with the soil matrix, which may cause increasing difficulty in subsequent remediation. Therefore, solar thermal treatment is inefficient in the metalloid removal.

\section{Conclusions}

Soils and mine waste samples from the abandoned $\mathrm{Hg}$ mine of Valle del Azogue (Almería province, Spain) were thermally treated in a rotary solar kiln to test the efficiency of the method on the mercury removal.

The SPTD determinations showed two different temperature ranges in which mercury was released from the samples: $200-250{ }^{\circ} \mathrm{C}$ and $300-330{ }^{\circ} \mathrm{C}$. Previous interpretations showed that the first $\mathrm{Hg}$ release peak indicates the $\mathrm{Hg}$ release from the solid matrix, whereas the second peak at higher temperatures indicates the presence of cinnabar. The first release peak is typically associated with calcine samples, and the second peak release is dominant in mining wastes and soils.

Experimental results showed a removal efficiency above $99 \%$ when the thermal treatment reaches $400{ }^{\circ} \mathrm{C}$, above the decomposition temperature of cinnabar $\left(310-330{ }^{\circ} \mathrm{C}\right)$, and similar results were reported by other studies. Mercury removal was highly efficient (more than $90 \%$ removal) in samples that showed a significant content of cinnabar and an equivalent diameter above $0.8 \mathrm{~mm}$. Moreover, the experimental results showed that the rotary kiln is more efficient than a fluidized-bed reactor, in order to remove mercury from contaminated soils and wastes.

\section{Acknowledgments}

This work was funded by The Spanish Ministry of Science and Technology (project REN2003-09247-C04-03 and ENE2006-13267-C05-01/ALT) in collaboration with the PSA-CIEMAT (Centro de Investigaciones Energéticas, Mediombientales y Tecnológicas), and the 2003-2004 Technical and Scientific Infrastructure Program (FEDER CIEM-E008). The authors wish to thank Dr. Ursula Kelm and Mónica Uribe for XRD analyses and interpretation. The technical support by the PSA Furnace personnel, especially Jose Galindo, is also greatly appreciated.

\section{Conflicts of Interest}

The authors declare no conflict of interest. 


\section{References}

1. U.S. Environmental Protection Agency. Treatment Technologies for Mercury in Soil, Waste and Water; EPA-542-R-07-003; Office of Superfund Remediation and Technology Innovation, U.S. Environmental Protection Agency: Washington, DC, USA, 2007.

2. Mulligan, C.N.; Yong, R.N.; Gibbs, B.F. Remediation technologies for metal-contaminated soils and groundwater: An evaluation. Eng. Geol. 2001, 60, 193-207.

3. Wang, J.; Feng, X.; Anderson, C.W.N.; Xing, Y.; Shang, L. Remediation of mercury contaminated sites-A review. J. Hazard. Mater. 2012, 221-222, 1-18.

4. Khan, F.I.; Husain, T.; Hejazi, R. An overview and analysis of site remediation technologies. J. Environ. Manag. 2004, 71, 95-122.

5. Matsuyama, A.; Iwasaki, H.; Higaki, K.; Yabuta, H.; Sano, T.; Akagi, H. Basic Study on the Remediation Technology of Mercury Compound-Contaminated Soil by Low-Temperature Thermal Treatment; Ebinghaus, R., Turner, R.R., de Lacerda, L.D., Vasiliev, O., Salomons, W., Eds.; Springer-Verlag: Berlin, Germany, 1999.

6. Chang, T.C.; Yen, J.H. On-site mercury-contaminated soils remediation by using thermal desorption technology. J. Hazard. Mater. 2006, 128, 208-217.

7. Kunkel, A.M.; Seibert, J.J.; Elliot, L.J.; Ricci, K.; Lynn, E.K.; Pope, G.A. Remediation of elemental mercury using in situ thermal desorption (ISTD). Environ. Sci. Technol. 2006, 40, 2384-2389.

8. Kucharski, R.; Zielonka, U.; Sas-Nowosielska, A.; Kuperberg, J.M.; Worsztynowicz, A.; Szdzuj, J. A method of mercury removal from topsoil using low-thermal application. Environ. Monit. Assess. 2005, 104, 341-351.

9. Lesa, B.; Aneggi, E.; Rossi, G.; Comuzzi, C.; Goi, D. Bench-scale tests on ultrasound-assisted acid washing and thermal desorption of mercury from dredging sludge and other solid matrices. J. Hazard. Mater. 2009, 171, 647-653.

10. Careghini, A.; Dastoli, S.; Ferrari, G.; Saponaro, S.; Bonomo, L.; De Propris, L.; Gabellini, M. Sequential solidification/stabilization and thermal process under vacuum for the treatment of mercury in sediments. J. Soils Sediments 2010, 10, 1646-1656.

11. Busto, Y.; Cabrera, X.; Tack, F.M.G.; Verloo, M.G. Potential of thermal treatment for decontamination of mercury containing wastes from chlor-alkali industry. J. Hazard. Mater. 2011, 186, 114-118.

12. Huang, Y.T.; Hseu, Z.-Y.; Hsi, H.H. Influences of termal decontamination on mercury removal, soil properties, and repartitioning of coexisting heavy metals. Chemosphere 2011, 84, 1244-1249.

13. Comuzzi, C.; Lesa, B.; Aneggi, E.; Dolcetti, G.; Goi, D. Salt-assisted thermal desorption of mercury from contaminated dredging sludge. J. Hazard. Mater. 2011, 193, 177-182.

14. Hua, J.M.; Wei, K.M.; Zheng, Q. Thermal desorption of mercury from gold-loaded granule activated carbon and its effect on gold elution. Hydrometallurgy 2012, 117-118, 86-92.

15. Navarro, A.; Cañadas, I.; Martínez, D.; Rodríguez, J.; Mendoza, J.L. Application of solar thermal desorption to remediation of mercury-contaminated soils. Sol. Energy 2009, 83, 1405-1414.

16. Navarro, A.; Biester, H.; Mendoza, J.L.; Cardellach, E. Mercury speciation and mobilization in contaminated soils of the valle del azogue $\mathrm{Hg}$ mine (SE, Spain). Environ. Geol. 2006, 49, 1089-1101. 
17. Biester, H.; Scholz, C. Determination of mercury binding forms in contaminated soils: Mercury pyrolysis versus sequential extractions. Environ. Sci. Technol. 1996, 31, 233-239.

18. Ministry of Housing, Spatial Plannin and the Environment. Circular on Target Values and Intervention Values for Soil Remediation; Ministry of Housing, Spatial Plannin and the Environment: The Hague, The Netherlands, 2000.

19. Román, R.; Cañadas, I.; Rodríguez, J.; Hernández, M.T.; González, M. Solar sintering of alumina ceramics: Microstructural development. Sol. Energy 2008, 82, 893-902.

20. Viladevall, M.; Font, X.; Navarro, A. Geochemical mercury survey in the Azogue Valley (Betic area, SE Spain). J. Geochem. Explor. 1999, 66, 27-35.

21. Biester, H.; Gosar, M.; Müller, G. Mercury speciation in tailings of the Idrija mercury mine. J. Geochem. Explor. 1999, 65, 195-204.

22. Navarro, A.; Cañadas, I.; Rodríguez, J.; Martínez, D. Leaching characteristics of mercury mine wastes before and after solar thermal desorption. Environ. Eng. Sci. 2012, 29, 915-928.

23. Navarro, A.; Cardellach, E.; Cañadas, I.; Rodríguez, J. Solar thermal vitrification of mining contaminated soils. Int. J. Miner. Process. 2013, 119, 65-74.

24. Taube, F.; Pommer, L.; Larsson, T.; Shchukarev, A.; Nordin, A. Soil remediation-mercury speciation in soil and vapor phase during thermal treatment. Water Air Soil Pollut. 2008, 193, $155-163$.

(C) 2014 by the authors; licensee MDPI, Basel, Switzerland. This article is an open access article distributed under the terms and conditions of the Creative Commons Attribution license (http://creativecommons.org/licenses/by/3.0/). 